\title{
Values of wisdom in Indonesian and German proverbs
}

\author{
Merry Lapasau *), \\ Universitas Indraprasta PGRI \\ *) Correspondences author: J1. Raya Tengah No. 80, Kel. Gedong, Kec. Pasar Rebo, Jakarta Timur 13760; Indonesia \\ e-mail: lapasaumerry@yahoo.com
}

\begin{abstract}
Since ancient times traditional societies continued their practical knowledge and life experiences through language from generation to generation so that each community group has a source of behavioral rules that can be used as a guide for life. Linguists, historians, anthropologists, social observers, cultural experts or literary specialists or anyone who wants to understand the concept of community life can have it from the expression of language in the form of advice, slogans, proverbs, phrases, anecdotes, parables and proverbs. This study discusses the time concepts contained in the Indonesian and German proverbs by focusing on the functions and values of wisdom contained therein. This research uses descriptive qualitative approach and is expected to explain about the philosophy, teaching and reflection of the height of thought of the ancient Indonesian people and the values contained in the German proverb.
\end{abstract}

Key Words: Indonesian Proverbs, German Proverbs, Concept of Time in Proverbs, Values in Proverbs.

Article History: Received: 15/10/2017; Revised: 17/11/2017; Accepted: 23/11/2017; Published: 20/12/2017

How to Cite (MLA 7 ${ }^{\text {th }}$ ): Lapasau, Merry. "Values of wisdom in Indonesian and German proverbs." Hortatori Jurnal Pendidikan Bahasa dan Sastra Indonesia 1.2 (2017): 116-125. Print/Online. Copyrights Holder: Lapasau, Merry. First Publication: Hortatori Jurnal Pendidikan Bahasa dan Sastra Indonesia (2017).

This work is licensed under a Creative Commons Attribution-ShareAlike 4.0 International License.

\section{Pendahuluan}

Dalam kehidupan masyarakat Indonesia, peribahasa diwariskan turun temurun untuk menyampaikan pesan-pesan berupa nasehat, tuntunan maupun teguran atau nilai-nilai kearifan yang mulia dan agung. Masyarakat Indonesia sejak dahulu telah merekam pemikiran mereka melalui peribahasa sebagai hasil dari interaksi manusia dalam berbagai aspek kemasyarakatan atau sosial, ekonomi dan politik berdasarkan pengamatan mereka yang tajam terhadap alam, adat dan budaya, pengalaman hidup dan sebagainya. Seperti kita ketahui, bahasa Indonesia berakar dari bahasa Melayu. Banyak sejarawan sepakat bahwa bukti keberadaan bahasa Indonesia dimulai di sekitar pesisir pulau Sumatera bagian tenggara dengan ditemukannya aksara pertama bahasa Melayu atau Jawi. Temuan tersebut mengindikasikan adanya penyebaran bahasa ini ke hampir seluruh tempat di Nusantara. Hal ini tidak lepas dari campur tangan kerajaan Sriwijaya yang saat itu menjadi penguasa jalur perdagangan di Nusantara.

Dalam budaya Melayu, terdapat tiga ciri pokok yang merupakan identitas masyarakat Melayu, yaitu berbahasa Melayu, beradat-istiadat Melayu, dan beragama Islam. Agama Islam merupakan pondasi pokok bangsa Melayu dalam menjalankan kehidupan sehari- hari. Masyarakat Melayu menjalankan kehidupan dengan berpedoman pada semboyan: adat-istiadat Melayu bersendikan syarak dan syarak bersendikan kitabullah. Pentingnya adat dalam kehidupan masyarakat Melayu berfungsi untuk mengatur hampir semua sisi kehidupan, memberikan arahan dan landasan dalam semua kegiatan, mulai dari hal yang besar sampai kepada hal yang paling kecil. Pada umumnya, masyarakat Melayu merupakan etnis yang sangat menjunjung tinggi adat istiadat, teguh serta memiliki kesetiaan terhadap nilai budaya yang dimilikinya dan hal tersebut tercermin dalam peribahasanya. Ada begitu banyak peribahasa dalam bahasa Melayu yang telah menjadi bagian dari budaya bangsa Indonesia yang memiliki makna dan nilai budaya yang tinggi. Dalam peribahasa, terkandung unsur budaya masyarakat yang berkaitan dengan nilai-nilai 
kearifan, pandangan hidup, norma, petunjuk dan aturan yang menjadi acuan bagi anggota masyarakat. Sebagai sastra lisan, maka perkembangan peribahasa sangat dipengaruhi oleh perubahan yang terjadi di masyarakat pendukungnya. Setiap perubahan di masyarakat biasanya juga diiringi dengan lenyapnya peribahasa yang tidak lagi sesuai dengan keadaan yang telah berubah tersebut. Sebaliknya, peribahasa yang masih sesuai dengan keadaan sekarang, akan bisa bertahan dan digunakan oleh masyarakat penutur. Peribahasa banyak digunakan dalam kehidupan keseharian masyarakat di masa lampau dan diturunkan dari generasi ke generasi karena dianggap sebagai jalan yang paling mudah bagi mereka untuk memberi nasihat, teguran atau sindiran. Peribahasa mempunyai bentuk yang ringkas dan padat sehingga isinya mudah ditangkap oleh pihak yang dinasehati. Bila kita menganalisis isi dan jiwa yang terkandung didalamnya, maka banyak hal yang dapat diambil dari sejarah, nilai-nilai budaya dan makna kehidupan masyarakat pada masa itu yang tercermin dalam peribahasa.

Bahasa Indonesia maupun bahasa Jerman mempunyai sejarah perkembangan yang cukup panjang sehingga memungkinkan kita untuk menggali nilai-nilai budaya yang terkandung dalam peribahasa dikedua bahasa tersebut. Sejarah dan perkembangan nilai- nilai moral bangsa Jerman identik dengan kearifan Prusia yang dikenal sejak era pencerahan (Aufklärung) dan didukung oleh raja Prusia Friedrich Wilhelm I. (1688-1713). Kearifan tersebut terutama menyangkut perihal ketepatan waktu, keteraturan dan kerajinan (Pünklichkeit, Ordnung und Flei $\beta$ ). Kearifan lainnya yang dijalani secara konkret oleh masyarakat Jerman di masa itu antara lain: Aufrichtigkeit (ketulusan), Bescheidenheit (kesederhanaan), Ehrlichkeit (kejujuran), Fleiß (kerajinan) dan Geradlinigkeit (bersikap lurus dan apa adanya). Gerechtigkeitssinn (prinsip keadilan dan melihat sesuatu sesuai nilainya /,Suum cuique“), Gewissenhaftigkeit (kesungguhan), Ordnungssinn (keteraturan), Pflichtbewusstsein (kesadaran akan kewajiban), Pünktlichkeit (ketepatan waktu), Redlichkeit (keselarasan antara perkataan dengan perbuatan), Sauberkeit (kebersihan), Sparsamkeit (hemat), Toleranz (bersikap toleran), Unbestechlichkeit (tidak menerima pemberian sogokan), Zurückhaltung/ Mehr sein als scheinen (rendah hati), Zielstrebigkeit (kemantapan usaha), Zuverlässigkeit (dapat diandalkan). Nilai- nilai kearifan Prusia ini masih sering disoroti hingga sekarang. Contohnya Ministerpräsident Brandenburg Matthias Platzeckin yang pada suatu debat politik menyerukan masyarakat Jerman untuk kembali ke nilai- nilai kearifan Jerman lama yaitu Anständigkeit (berkelakuan sesuai norma yang berlaku), Verlässlichkeit (dapat diandalkan) und Pflichterfüllung (memenuhi kewajiban).

Peribahasa Jerman secara tertulis dapat ditelusuri awal keberadaannya sejak abad ke 16 dan ditemukan pada karya Johannes Agricola (750 erklärte Sprichwörter. Edisi Hagenau 1534, text lengkap edisi Wittenberg 1582). Dalam kehidupan berbudaya di Abad Pertengahan di Jerman, peribahasa digunakan di semua bidang kehidupan dan dianggap sebagai sarana ekspresi yang bernilai tinggi. Sejak abad ke-12 banyak buku teks retorika yang menyarankan penggunaan peribahasa sebagai gaya bahasa untuk mendukung kebenaran tulisan mengenai didaktik. Ceramah keagamaan abad pertengahan juga sering menggunakan peribahasa selain kata-kata bijak atau kutipan yang diambil dari kitab suci.

\section{Metode}

Kajian ini menggunakan pendekatan metode kualitatif. Metode ini mengacu pada prosedur penelitian yang menghasilkan data deskriptif seperti misalnya kata-kata lisan dan tulisan dan juga perilaku yang dapat diamati (Bogdan dan Biklen, 1982). Merujuk pada Subroto (1992:7), dalam hal ini peneliti mencatat data dalam bentuk satuan lingual berupa frasa dan atau kalimat, yang merupakan peribahasa dalam Bahasa Indonesia dan Jerman dari sumber data. Penetapan keabsahan data meliputi derajat kepercayaan, keteralihan, kebergantungan, dan kepastian (Moleong, 2004). Penelitian kualitatif bertujuan untuk memperoleh gambaran seutuhnya mengenai suatu hal menurut pandangan manusia yang diteliti. Penelitian kualitatif berhubungan dengan ide, persepsi, pendapat atau kepercayaan orang yang diteliti dan kesemuanya tidak dapat diukur dengan angka.

Selanjutnya dijelaskan oleh David Williams (1995) seperti yang dikutip Moleong (2007:5) bahwa penelitian kualitatif adalah pengumpulan data pada suatu latar alamiah, dengan menggunakan metode alamiah, dan dilakukan oleh orang atau peneliti yang tertarik secara alamiah. Dalam penelitian ini, keabsahan data dicapai dengan menggunakan kredibilitas dan kepastian. Kredibilitas bertujuan untuk mencapai kesahihan data. memahami fenomena tentang apa yang dialami oleh subjek penelitian misalnya perilaku, persepsi, motivasi, tindakan, dll., secara holistik, dan dengan cara deskripsi dalam bentuk kata- 
kata dan bahasa, pada suatu konteks khusus yang alamiah dan dengan memanfaatkan berbagai metode alamiah.

Berdasarkan keterangan dari beberapa ahli di atas, dapat ditarik kesimpulan bahwa penelitian deskriptif kualitatif adalah rangkaian kegiatan untuk memperoleh data yang bersifat apa adanya tanpa ada dalam kondisi tertentu yang hasilnya lebih menekankan makna. Peneliti menggunakan metode penelitian deskriptif kualitatif karena penelitian ini mengeksplor fenomena peribahasa yang dapat ditemui di hampir semua bahasa dengan sejarah budaya yang panjang, dalam hal ini peneliti memilih bahasa Indonesia dan bahasa Jerman untuk membandingkan makna dan nilai-nilai kearifan yang terkandung dalam peribahasa di dunia timur dan barat serta untuk mendeskripsikan bagaimana kedua budaya tersebut memaknai konsep waktu yang terdapat dalam peribahasa mereka. Untuk mencapai tingkat keabsahan data, peneliti melaksanakan observasi secara mendalam terhadap data. Selain itu, kredibilitas penelitian ini dicapai dengan pengecekan oleh teman sejawat dan kecakupan referensi. Makalah ini hanya membahas peribahasa terpilih yang berkaitan dengan konsep waktu yang mengandung nilai- nilai kearifan tertentu sebab tidak semua peribahasa yang berkaitan dengan konsep waktu mengandung nilai- nilai kearifan.

\section{Hasil dan Diskusi}

\section{Peribahasa}

Peribahasa (Proverbs, Parömien) adalah ungkapan tradisional masyarakat tentang perilaku, kebiasaan setempat atau keadaan yang biasanya merupakan pengalaman hidup. Peribahasa seperti halnya frase idiom merupakan bagian penting dari perbendaharaan kosakata di hampir setiap bahasa. Selain itu, peribahasa juga merupakan salah satu bentuk gaya bahasa yang berupa ungkapan tradisional atau suatu kiasan bahasa yang berupa kalimat atau kelompok kata yang bersifat padat, ringkas, sederhana dan berisi tentang norma, nilai, nasihat, perbandingan, perumpamaan, prinsip dan aturan tingkah laku. Dalam linguistik, kajian tentang peribahasa sebagai suatu disiplin ilmu disebut Parömiologie (paremiology) yang berasal dari kata тароніа (paroimía) dalam bahasa Yunani.

Menurut KBBI (1990: 671), peribahasa adalah kelompok kata atau kalimat yang tetap susunannya dan biasanya mengisahkan maksud tertentu. Dalam peribahasa termasuk juga bidal, ungkapan, perumpamaan, atau kalimat-kalimat ringkas, padat yang berisi perbandingan, perumpamaan, nasihat, prinsip hidup dan aturan tingkah laku.

Sedangkan menurut Bussmann dalam Leksikon Linguistik (2002:616), peribahasa yang juga disebut proverb merupakan ungkapan yang diformulasikan dengan singkat, padat dan tepat yang mengandung pengalaman hidup masyarakat. Pengarangnya biasanya tidak dikenal dan menggambarkan keadaan masyarakat saat itu. Sedangkan menurut Schneider (1987), ahli linguistik Jerman, tidak terdapat batasan yang jelas antara peribahasa yang pengarangnya tidak diketahui dan kutipan (quotation) yang nama pengarangnya jelas diketahui. Kutipan biasanya merupakan pengalaman individu yang bisa juga menjadi peribahasa jika digunakan secara luas. Banyak judul buku dan judul film yang juga megadaptasi karakter peribahasa. Bahkan refrain lagu rakyat yang dipendekkan banyak yang sudah diakui dan digunakan sebagai peribahasa Jerman secara luas.

Peribahasa biasanya berupa kalimat pendek yang dikenal masyarakat umum yang mengandung kebenaran, kebijaksanaan dan tradisi yang disampaikan secara metaforis. Bentuk peribahasa yang mudah diingat dan isinya yang berupa pengalaman hidup, membuat mereka mudah populer dan menjadi sarana praktis berekspresi melalui bahasa. Secara umum, peribahasa ditandai terutama oleh lima karakteristik sebagai berikut: peribahasa merupakan kesatuan kalimat yang tetap dan stabil, memiliki bentuk yang mudah diingat, populer dikalangan masyarakat, kandungannya cenderung berupa pengajaran pengalaman hidup dan biasanya menggambarkan sesuatu melalui perumpamaan. Selain itu, peribahasa biasanya terdiri dari beberapa kata atau kalimat dan mempunyai makna idiomatik tersendiri. Jika suatu peribahasa mempunyai ungkapan yang sangat baik, maka ia disebut dengan istilah aforisme.

Aristoteles menilai peribahasa sebagai peninggalan nilai- nilai kearifan lama yang memuat pemikiran dan pengalaman hidup generasi sebelumnya. Penilaian tersebut sesuai dengan karakter peribahasa yang memuat pengajaran tentang kehidupan. Sampai sekarang masyarakat dengan budaya modern masih mengunakan peribahasa dalam konsep tradisional sebagai peringatan, kritik, panduan berumah tangga, ataupun juga sebagai peraturan tak tertulis. Peran penting yang dimainkan peribahasa 
menunjukan bahwa peribahasa bukanlah fenomena bahasa yang mudah punah. Penggunaan peribahasa dalam iklan di radio dan media lain dengan bentuk yang sedikit dirubah menjadikan peribahasa tampil dalam berbagai variasi dengan singkatan, penyederhanaan ataupun sedikit gubahan.

\section{Konsep Nilai}

Nilai dalam konteks bahasa sehari hari merujuk kepada sesuatu yang diinginkan yang berupa sifat atau kualitas moral, objek, ide, cita-cita, pola tindakan, karakter dan digunakan sebagai prinsip atau standar dalam hidup bermasyarakat. Sistem nilai terbentuk dari gambaran nilai-nilai sebagai suatu yang bersifat idealitas atau nilai-nilai yang berlaku di masyarakat secara keseluruhan. Nilai- nilai yang saling terkait, namun memiliki penilaian yang berbeda di mata masyarakat disebut hirarki nilai. Nilai dapat dipahami dalam arti material dan moral. Suatu nilai diperoleh dengan cara terpisah, yaitu dihasilkan oleh pengalaman budaya, masyarakat dan pribadi yang tertuang dalam struktur psikologis individu, oleh karena itu, nilai menjadi tahan lama dan stabil sehingga dapat dikatakan bahwa nilai memiliki kecenderungan untuk menetap, walaupun masih mungkin berubah karena hal-hal tertentu. Salah satu hal yang menjadi penyebab berubahnya suatu nilai adalah bila terjadi perubahan budaya di mana individu tersebut menetap.

Bochenski (1995) membedakan tiga kelompok nilai- nilai non materi yang dapat dimanifestasikan melalui tindakan, yaitu: nilai moral, nilai estetika dan nilai religius.

a. $\quad$ Nilai moral merujuk kepada anjuran tindakan, sesuatu yang sepatutnya dilakukan

b. Nilai estetika merujuk kepada suatu keadaan yang sesuai kenyataan

c. Nilai religius sebagai jembatan antara nilai moral dan nilai estetika yang juga memperhatikan sesuatu yang tidak sepatutnya dilakukan dan sesuatu yang tidak sesuai kenyataan yang dimanifestasikan dalam istilah dosa.

\section{Bentuk dan fungsi peribahasa Indonesia}

Peribahasa biasa digunakan untuk menyindir atau memperindah bahasa. Kata-kata dalam peribahasa merupakan susunan yang pasti dan tidak dapat diubah. Bentuk peribahasa Indonesia antara lain sebagai berikut:

1. Pepatah

Pepatah adalah jenis peribahasa yang berisi nasihat atau ajaran dari orang tua. Contoh:

a. "Air tenang menghanyutkan" berarti orang pendiam tetapi banyak ilmu. b. "Setinggi-tinggi bangau terbang, hinggapnya ke kubangan" berarti walaupun ke mana juga seseorang pergi, kelak tentu kembali ke negeri sendiri.

c. "Lempar batu sembunyi tangan" artinya berbuat suatu keonaran tetapi pura-pura tidak tahu.

2. Perumpamaan atau ibarat

Perumpamaan adalah jenis peribahasa yang berisi perbandingan yang menggunakan kata seperti, sebagai, bagai, bak, atau laksana.

Contoh:

a. "Seperti pungguk merindukan bulan" berarti mengharap-harapkan sesuatu yang tidak mungkin tercapai.

b. "Bagai makan buah simalakama, dimakan ibu mati, tak dimakan bapak mati", berarti serba sulit dalam menentukan sikap atau tindakan.

c. "Seperti ilmu padi, semakin berisi semakin merunduk" artinya orang yang berilmu tinggi tidak akan menyombongkan diri

\section{Pemeo}

Pemeo adalah jenis peribahasa yang dijadikan semboyan.

Contoh:

a. "Ringan sama dijinjing, berat sama dipikul" berarti seia sekata, senasib sepenanggungan.

b. "Patah sayap, bertongkat paruh" berarti tidak berputus asa.

c. "Esa hilang, dua terbilang", Tetap hati mengerjakan suatu pekerjaan yang berbahaya 
Sedikitnya ditemukan ada tiga fungsi yang terkandung dalam peribahasa-peribahasa Indonesia, yaitu untuk menasehati, menegur, dan menyindir.

a. Untuk menasehati

Peribahasa-peribahasa yang berfungsi untuk menasehati biasanya berisi tentang nilai-nilai kehidupan yang bijak demi terciptanya kehidupan yang tentram dan baik. Nasehat biasanya diberikan orangtua kepada anakanaknya.

b. Untuk menegur

Menegur artinya memberikan peringatan supaya orang tidak melakukan seperti yang disebutkan dalam peribahasa. Jika orang masih melakukannya, maka kemungkinan akan ada konsekuensi yang harus ditanggung.

c. Untuk menyindir

Menyindir merupakan tindakan untuk menegur seseorang secara tidak langsung atau secara halus, dengan harapan orang yang disindir tidak terlalu tersinggung dan mengerti maksud yang ingin disampaikan.

\section{Asal usul peribahasa Jerman}

Walaupun karakteristik umum peribahasa adalah keanoniman pengarangnya, namun banyak peribahasa Jerman yang tidak berasal dari pengalaman hidup penuturnya secara umum tetapi berasal dari budaya bahasa Latin atau diambil dari Alkitab yang masuk ke bahasa Jerman melalui terjemahan oleh Martin Luther. Selain itu, kitab- kitab teologi kuno, mantera- mantera dari jaman pra-agama, puisi kuno, nyanyian rakyat, moto atau slogan rakyat dari abad pertengahan juga merupakan sumber peribahasa Jerman.

Dalam bahasa Jerman juga terdapat beberapa ungkapan bernas dari karya sastra yang begitu populer sehingga mereka sekarang secara luas dianggap sebagai peribahasa, meskipun asal mereka masih dapat dideteksi, contohnya:

- „Die Axt im Haus erspart den Zimmermann“ (harfiah: kapak dalam rumah dapat menghemat tukang). ungkapan ini merupakan anjuran agar kita mempersiapkan diri dengan perkakas rumah tangga yang dapat membantu kita jika ada sesuatu di dalam rumah yang perlu diperbaiki sehingga kita tidak perlu mengeluarkan uang untuk membayar tukang. Ungkapan ini berasal dari karya sastra seorang penulis terkenal yaitu Friedrich Schiller dalam naskah dramanya Wilhelm Tell yang ia tulis tahun 1804. Ungkapan ini begitu populer sehingga masyarakat secara luas sudah menerimanya dan menjadi peribahasa yang digunakan sehari hari.

- „Drum prüfe, wer sich ewig bindet. Ob sich das Herz zum Herzen findet!der Wahn ist kurz der Reu ist lang” (harfiah: oleh karena itu, telitilah siapa yang ingin menikah, apakah benar- benar dari hati. Karena kegilaan hanya sesaat dan penyesalan akan panjang). Peribahasa ini berasal dari kumpulan puisi Friedrich Schiller Das Lied von der Glocke Peribahasa ini bermakna orang harus hati- hati bila ingin menikah apakah merasa sudah benar benar cocok dengan pasangannya karena jika salah memilih pasangan, kebahagiaan akan punah dengan cepat dan orang akan menyesal.

Karakteristik utama dari peribahasa adalah gambaran yang ditampilkan melalui perumpamaan. Melalui ungkapan allegorisme misalnya, peribahasa mencoba mengungkapkan suatu ide atau menampilkan suatu kenyataan dalam bentuk lain untuk menghindari ungkapan yang terlalu jelas agar tidak menyinggung orang lain. Sebuah peribahasa dapat memuat perumpamaan, tetapi terdapat juga sejumlah peribahasa tanpa perumpamaan yang disebut peribahasa abstrak.

Berdasarkan karakter tersebut, maka peribahasa dapat dibagi dalam dua kategori: Di satu sisi terdapat peribahasa yang maknanya dapat dipahami jelas melalui elemen dalam kalimatnya dan di sisi lain terdapat 
peribahasa yang maknanya tersirat dan tidak diungkapkan secara eksplisit dalam kalimat. Selanjutnya, terdapat peribahasa yang berada antara dua kategori tersebut dan dengan demikian dapat dipahami baik secara harfiah dan dalam arti konotatif, contohnya: Keine Rose ohne Dormen. ungkapan ini dapat dimengerti secara harfiah sebagai: tidak ada bunga mawar tanpa duri, namun arti konotasinya adalah tidak ada kecantikan yang sempurna. Sebuah peribahasa dengan bentuknya yang praktis dan makna yang tersurat seperti contoh diatas dapat menjadikannya mudah dimengerti dan diingat.

\section{Bentuk dan fungsi peribahasa Jerman}

Bentuk peribahasa yang tetap dan tidak berubah membedakannya dari ungkapan idiom. Artinya, elemen yang ada dalam satu peribahasa tidak dapat diganti dengan elemen lain tanpa merubah maknanya. Contoh peribahasa dengan elemen yang stabil:

- „Hunger ist der beste Koch“: rasa lapar adalah koki terbaik. Dalam peribahasa ini, tidak boleh ada satu elemen yang diganti karena akan menyebabkan perbahasa tersebut kehilangan makna yang ingin disampaikan yaitu: masakan yang dimasak oleh siapapun akan terasa nikmat jika orang yang makan hidangan tersebut dalam keadaan lapar.

- „Wo ein Wille ist, ist auch ein Weg“ bermakna dimana ada kemauan, di situ ada jalan. Peribahasa ini tidak dapat diganti misalnya dengan ungkapan dimana ada uang disitu ada jalan walaupun dalam praktek kehidupan hal tersebut mungkin saja terjadi.

Seringkali bentuk peribahasa Jerman masih sangat diperkuat dengan aliterasi, pengulangan suku kata atau huruf awal atau akhir. Contohnya seperti:

- „Glück und Glas - wie leicht bricht das" (kebahagiaan dan gelas- keduanya sangat mudah hancur)

- "Was ich nicht weiß, macht mich nicht heiß $\beta^{\prime \prime}$. (apa yang saya tidak tau, tidak akan meresahkan saya)

- "Trocken Brot macht Wangen rot " (roti kering membuat pipi memerah)

- "Geteiltes Leid ist halbes Leid “ (kesedihan akan berkurang jika dihadapi bersama)

- „Geteilte Freude ist doppelte Freude“ (kebahagiaan akan bertambah jika dinikmati bersama)

\section{Fungsi peribahasa Jerman}

Seperti halnya peribahasa Indonesia, peribahasa Jerman juga mempunyai fungsi sosial yang berlaku di masyarakat walaupun pada prakteknya tidak digunakan di semua kalangan pengguna bahasa. Pada dasarnya, masyarakat Jerman khususnya generasi tua dan kalangan atas berpendidikan tinggi memang terbiasa menggunakan peribahasa dalam komunkasi sehari hari sebagai bagian dari penguasaan bahasa. Peribahasa Jerman mmepunyai fungsi sosial antara lain sebagai berikut:

\section{1) sebagai Kritik sosial}

Contoh Peribahasa Jerman yang mencerminkan kritik sosial terhadap pemerintah kekaisaran di jaman pertengahan: „Als Adam grub, und Eva spann, wo war denn da der Edelmann? (ketika Adam mencangkul dan Eva menenun, dimana para bangsawan?) Peribahasa ini berfungsi sebagai kritik sosial karena jaman dahulu di Jerman para petani diexploitasi oleh para bangsawan dan pemilik lahan namun mereka tidak memperhatikan kesejahteraan petani. Para petani kemudian menuntut agar jabatan bangsawan dan kaum cendekiawan sebagai otoritas mutlak harus dihapuskan dan petani dapat mengabdi kepada kaisar secara langsung.

\section{2) arahan untuk menilai dengan bijaksana}

Contoh: „Es ist nicht alles Gold, was glänzt.“ (tidak semua yang bersinar itu emas). Hal ini dimaksudkan agar kita tidak menilai sesuatu berdasarkan tampilan luar yang bagus, karena hasilnya mungkin akan mengecewakan atau tidak sesuai dengan tampilannya. 


\section{3) filosofi kehidupan}

Contoh peribahasa Jerman yang mengandung filosofi kehidupan: „Ein gebranntes Kind scheut das Feuer."( anak kecil yang pernah terkena panas, akan menjauhi api). Peribahasa ini bermakna bahwa orang harus bisa mengambil pelajaran dari kesalahan yang pernah ia perbuat sebagai pengalaman yang berharga.

\section{4)Pendapat atau keputusan}

„Gute Ware lobt sich selbst.“(suatu barang yang bagus akan terlihat dari kualitasnya). Peribahasa ini bermakna bahwa orang yang mempunyai suatu kelebihan tidak perlu memamerkan kelebihannya karena orang lain akan tau melalui prestasinya.

„Lieber den Spatz in der Hand als die Taube auf dem Dach.“ lebih baik punya burung pipit di tangan daripada burung merpati yang masih di atap rumah. Peribahasa ini menyatakan pendapat bahwa orang sebaiknya bersyukur atas yang dimiliki dan tidak menginginkan yang tidak dimiliki.

Secara umum peribahasa dapat mendukung pendapat dalam suatu tindak tutur, menggarisbawahi atau mengkonfirmasi dan dengan begitu sekaligus menandai puncak atau kesimpulan dari suatu percakapan.

\section{Konsep waktu}

Waktu atau masa menurut Kamus Besar Bahasa Indonesia (1997) adalah seluruh rangkaian saat ketika suatu proses, perbuatan, atau keadaan sedang berada atau berlangsung. Dalam hal ini, skala waktu merupakan interval antara dua buah keadaan atau kejadian, atau bisa juga merupakan lama berlangsungnya suatu kejadian. Jenis-jenis pengukur waktu atau jam adalah: Jam matahari, Jam analog, Jam digital. Skala waktu diukur dengan satuan, yaitu: detik, menit, jam, hari (Senin,Selasa, Rabu, Kamis, Jumat, Sabtu, Minggu) pekan (minggu), bulan (Januari, Februari, Maret, April, Mei, Juni, Juli, Agustus, September, Oktober, November, Desember), triwulan/ caturwulan/semester/musim, tahun, windu, dekade (dasawarsa) abad, milenium dan seterusnya.

Persepsi waktu adalah istilah kolektif yang tidak terlalu jelas batasannya untuk menggambarkan fenomena kognitif seperti perasaan terhadap waktu, simultanitas / berurutan, waktu subjektif atau kualitas waktu. Persepsi manusia terhadap waktu bukan hanya terbatas seperti cara ia melihat berputarnya jarum jam sambil berpikir untuk melakukan sesuatu pada waktunya. Masyarakat mempersepsi waktu sebagai suatu kesempatan untuk berkarya dengan segala kebebasan. Kebebasan waktu terjadi jika orang mampu memanfaatkan waktu dengan efisien untuk menciptakan suatu karya yang berguna bagi dirinya dan orang lain. Waktu menggambarkan urutan peristiwa, sehingga, tidak seperti kuantitas fisik lainnya yang unik, arah waktu bersifat ireversibel, jadi tidak bisa diputar ulang. Dari perspektif filosofis, waktu digambarkan sebagai langkah ke depan dari masa sekarang yang berangkat dari masa lalu dan menuju masa depan.

Dari sudut pandang sosiologi, konsep waktu diperlukan masyarakat untuk memudahkan pengambilan keputusan, menghindari stres dalam menyelesaikan tugas mereka jika sebelumnya telah ditetapkan waktunya untuk mengelola urusan mereka dan untuk mengkoordinasikan tindakan mereka. Pengelolaan waktu dapat dipermudah dengan memanfaatkan kalender dengan waktu yang tetap (tahun, bulan, minggu, dan hari libur, dll) dan fungsi (misalnya sebagai hari keagamaan, nasional atau internasional, sebagai kejadian bersejarah yang biasanya diperingati berulang secara berkala. Tergantung pada kompleksitas tatanan sosial, terdapat konsep waktu untuk pembagian usia dengan fungsi masingmasing yang ditentukan masyarakat setempat, seperti saat bayi, saat masa kanak-kanak, remaja, saat dewasa, usia tua atau saat TK, sekolah, waktu belajar atau magang, kerja yang dibayar, atau waktu santai. Dalam waktu sosial ini, masyarakat dapat mengisi biografi masing-masing seperti waktu kelahiran, waktu upacara keagamaan, waktu pergi ke sekolah, karir sekolah, studi atau masuk kerja, pernikahan dan lainlain.

Dalam ungkapan bahasa sehari-hari, persepesi subjektif tentang waktu berkaitan dengan pemahaman waktu secara objektif. Pada saat yang sama terdapat penilaian pribadi pengguna bahasa tentang peristiwa yang ia alami atau keadaan di sekitarnya seperti yang diutarakan melalui ungkapan seperti: saya 
tidak punya waktu, sesuatu berlalu dengan berjalannya waktu, memakan waktu, mengulur waktu, mendapatkan waktu lebih, memberikan waktu kepada seseorang, mencuri waktu, membunuh waktu, menjalani waktu yang tersisa dan lain-lain.

\section{Nilai-nilai kearifan dalam peribahasa Jerman}

\section{1) Kedisiplinan/ tepat waktu}

- ,besser eine Stunde zu früh als eine Minute zu spät": lebih baik lebih awal satu jam daripada terlambat satu menit.

- „Punktlichkeit ist die Höflichkeit der Könige": tepat waktu adalah rajanya kesopanan

- „Wer nicht kommt zur rechten Zeit, der muss essen, was übrig bleibt": Siapa yang tidak datang tepat waktu, harus makan apa yang tersisa. Peribahasa ini dapat ditemui dalam berbagai variasi seperti: „Wer nicht kommt zur rechten Zeit, der muss nehmen, was übrig bleibt": siapa yang tidak datang tepat waktu, harus menerima apa yang tersisa atau „Wer nicht kommt zur rechten Zeit, der muss sehen, was übrig bleibt": siapa yang tidak datang tepat waktu, harus melihat apa yang tersisa untukmya.

2) Nasehat untuk melakukan atau menilai sesuatu tidak terburu-buru „man soll den Tag nicht vor dem Abend loben": jangan menilai sesuatu sebelum segalanya jelas.

„Rom ist auch nicht an einem Tag erbaut worden" : Roma tidak dibangun dalam satu hari, maknanya adalah projek besar memang membutuhkan waktu untuk menyelesaikannya.

„Eile mit Weile": biar lambat asal selamat. Peribahasa ini dikenal dalam bahasa Latin di jaman Pertengahan sebagai „Festina lente" atau dalam bahasa Jerman awal „Eilen tut kein gut".

\section{3) Nasehat memulai sesuatu dari masa muda}

„,Was Hänschen nicht lernt, lernt Hans nimmermehr": apa yang Hans tidak pelajari semasa muda, tidak akan dia bisa kejar dimasa tuanya.

,früh übt sich, wer ein Meister werden will": siapa yang ingin menjadi ahli dalam suatu bidang, harus mempelajarinya sejak kecil

„früh krümmt sich, was ein Häkchen werden will" mempunyai arti harfiah: kalau mau menjadi tanda petik, harus belajar bengkok dari kecil yang maksudnya: untuk mencapai sesuatu, orang harus berusaha dari awal.

\section{4) Nasehat untuk berusaha dan bekerja keras}

„,Man muss sich nach der Zeit richten, die Zeit richtet sich nicht nach uns": Kita harus menyesuaikan diri dengan waktu karena waktu tidak menyesuaikan dengan kita.

„,der frühe Vogel fängt den Wurm": burung yang keluar pagi hari akan dapat menangkap cacing

\section{5) nasehat untuk tidak menunda pekerjaan}

„Was du heute kannst besorgen, das verschiebe nicht auf morgen": jangan menunda sampai esok apa yang bisa dilakukan hari ini.

„Verschiebe nicht auf morgen, was du heute kannst besorgen": jangan menunda pekerjaan sampai esok yang bisa dikerjakan hari ini. Peribahasa ini hadir dalam versi yang sama maknanya: „,Was du heute kannst besorgen, das verschiebe nicht auf Morgen".

„,Morgenstund hat Gold im Mund": Orang yang memulai kerja di pagi hari akan membawa hasil yang banyak.

„,Wer zuerst kommt, mahlt zuerst": siapa yang datang lebih awal, dapat memulai pekerjaan lebih dahulu sehingga jalan sukses akan terbuka.

\section{6) nasehat untuk bersabar}

„Gutes braucht seine Zeit": sesuatu yang bagus memerlukan waktu

„Kommt Zeit kommt Rat": solusi suatu masalah akan datang pada waktunya 
„Jede Flut hat ihre Ebbe": Setiap pasang ada surutnya

„Es gibt Tage, da verliert man und es gibt Tage, da gewinnen die Anderen": Ada hari kita sukses, namun di hari lain orang lain yang sukses

„Zeit heilt alle Wunden": waktu menyembuhkan semua luka

\section{Simpulan}

Penelitian ini menggunakan pendekatan kualitatif dengan menganalisis 4032 data peribahasa Indonesia dan 4300 peribahasa Jerman. Dari keseluruhan data tersebut, ditemukan sebanyak 15 peribahasa Indonesia dan 45 peribahasa Jerman yang memuat konsep waktu. Sedikitnya ditemukan ada tiga fungsi yang terkandung dalam peribahasa-peribahasa Indonesia, yaitu untuk menasehati, menegur, dan menyindir. Selanjutnya, data dianalisis untuk menjawab tiga permasalahan penelitian dengan hasil penelitian: (1) Peribahasa dibedakan ke dalam tiga bentuk, yaitu pepatah, pemeo, dan perumpamaan (2) nilai- nilai kearifan, nilai moral, nasehat dan ungkapan positif yang terkandung dalam peribahasa Indonesia yang mengusung konsep waktu yaitu: (a) nasehat agar bersabar dalam melakukan sesuatu, (b) nasehat agar melakukan sesuatu sesuai waktunya (c) nasehat agar belajar sesuatu dari masa muda (d) nasehat agar menghargai waktu. Sedangkan nilai-nilai kearifan, nilai moral, nasehat dan ungkapan positif dalam peribahasa Jerman dengan konsep waktu yaitu: (a) nasehat untuk bersabar, (b) nasehat untuk berusaha dan bekerja keras, (c) nasehat untuk belajar sesuatu dari masa muda (d) nasehat untuk tidak menunda pekerjaan, (e) nasehat untuk melakukan atau menilai sesuatu tidak terburu-buru (f) nilai kedisiplinan/ tepat waktu, (g) nasehat untuk berhemat dimasa muda.

Peribahasa Indonesia tidak dapat ditelusuri asal terjadinya dan pengarangnya anomin sedangkan peribahasa Jerman pengarangnya tidak selalu anomin dan masih dapat ditelusuri asalnya. Baik peribahasa Indonesia maupun Jerman menggunakan kata yang jelas untuk menggambarkan waktu seperti: pagi, sore, masa kecil, lambat, cepat dan lain-lain. Peribahasa Indonesia tidak mengenal bentuk pengulangan sedangkan peribahasa Jerman banyak menggunakan bentuk pengulangan huruf atau suku kata. Terdapat beberapa peribahasa Indonesia yang mempunyai makna kurang lebih sama dengan peribahasa Jerman. Persepsi Indonesia tentang waktu yang diungkapkan dalam peribahasa dapat juga ditemukan dalam peribahasa Jerman dan sebaliknya, contohnya: "Melentur biarlah waktu rebung": „Was Hänschen nicht lernt, lernt Hans nimmermehr".,,früh übt sich, wer ein Meister werden will", „früh krümmt sich, was ein Häkchen werden will"; "biar lambat asal selamat, takkan lari gunung dikejar", "lambat laga asalkan menang" „Eile mit Weile",gut Ding will Weile haben".

Bangsa Jerman dikenal sebagai bangsa yang sangat menghargai waktu dan hal itu tercermin dari banyaknya peribahasa yang memuat konsep waktu. Peribahasa Jerman menyampaikan sesuatu lebih langsung dengan maknanya lebih positif. Berbeda dengan peribahasa Jerman, peribahasa Indonesia banyak yang tidak bersifat langsung tetapi menjelaskan akibat buruk jika misalnya menunda-nunda pekerjaan. Perbedaan tersebut dilatarbelakangi oleh retorika, pola pikir, dan budaya masing- masing negara. Perbedaan lain menyangkut bentuk dan keanoniman pengarang dalam peribahasa Indonesia. Hal tersebut dapat dijelaskan dengan keberadaan sastra lisan Jerman yang sejak abad pertengahan sudah sangat stabil, maka banyak ungkapan dari pengarang terkenal yang kemudian menjadi peribahasa, hal tersebut tidak ditemukan dalam peribahasa Indonesia.

\section{Ucapan Terima Kasih}

Terima kasih kepada dosen pengajar di program pascasarjan Universitas Indraprasta PGRI atas bimbingannya dalam penulisan artikel ini.

\section{Daftar Rujukan}

Badudu, J.S. Kamus Peribahasa. Jakarta: Kompas Media Nusantara, 2008.

Bogdan, Robert C dan S.K Biklen. 1982. Qualitative Research for Education: An Introduction to Theory and Method. Boston: Allyn and Bacon, 1982.

Bussmann, Hadumond. Lexikon der Sprachwisssenschaft. Stuttgar: tAlfred Kröner, 2002. 
Burger, Harald. Phraseologie. Eine Einführung am Beispiel des Deutschen. Schmidt: Berlin, 2010. Donalie, Elke. Basiswissen Deutsche Phraseologie. Francke: Tübingen/ Basel, 2009.

Koller, Werner. Redensarten. linguistische Aspekte, Vorkommensanalysen, Sprachspiel. Tübingen: Niemeyer, 1977.

Moleong, Lexy J. Metodologi Penelitian Kualitatif. Bandung: PT. Remaja Rosdakarya, 2004.

Pamuntjak, K.St et al. Peribahasa. Jakarta: Balai Pustaka, 2004.

Peukes, Gerhard. Untersuchungen zum Sprichwort des Deutschen. Semantik, Syntax, Typen. Schmidt: Berlin, 1977.

Pilz, Klaus Dieter. Phraseologie. Redensartenforschung. Metzler: Stuttgart, 1981.

Röhrich, Lutz . Das große Lexikon der sprichwörtlichen Redensarten. Bd. 1. Herder: Freiburg, 1991. https://www.redensarten-index.de/suche.php 15. 5. 2017

https://de.wikiquote.org/wiki/Deutsche_Sprichwörter 16.5.2017

https://de.wikipedia.org/wiki/Sprichwort 21.5.2017

http://www.peribahasaindonesia.com/ 21. 6. 2017

https://id.wikipedia.org/wiki/Waktu 22. 8. 2017 